\title{
An Examination of Networked Politics and the Policy Process at the High \\ Peace Council (HPC) of Afghanistan
}

15 October 2012

Dissertation for the Completion of the MSc Public Policy

School for Policy Studies

University of Bristol

Reza Kateb

Word count: 14,620 


\section{Acknowledgements}

First, I am especially grateful to my beloved wife, son, parents, brothers and sisters. Thank you so very much for all the love, patience and support. For being so understanding and giving me care when things started to look difficult. Also I am thankful to Khaliqyar Haidari, my best friend whom provided me personal loan to study in the UK.

I would like to express my heartfelt gratitude to my supervisor Dr. Sarah Ayres without whom this dissertation could not have been written. Many thanks for all the insights, encouragement and support. I am also grateful to all the respected interviewees who offered their precious time in responding to my research questions. Their contributions were of a great help in writing this dissertation.

I am delighted in using this opportunity to thank the School for Policy Studies and especially to Ann Singleton being my tutor providing good advice throughout the MPP program.

To the great people who are very important for me, the Karyabe team being my closest friends. Thank you for helping me during my field research. And finally my sincere gratitude to all those who helped me in every way they could in completing this dissertation work. 


\section{ABSTRACT}

The study seeks to examine networked politics and the policy process at the High Peace Council (HPC) of Afghanistan. Face-to-face semi-structured interviews were conducted to gain understanding of the experiences and perceptions of being in a networked politics. The aim of dissertation is to address this question: What network of contact the HPC of Afghanistan is using to strike a peace deal with the Taliban and other armed groups? Through supporting literature this study examined the networked politics and policy network relations in post conflict society. The study found that HPC publicises the government's objectives for gaining public support. Within the umbrella of HPC, the study indentified four categories of negotiation networks dealing with the armed oppositions: (i) between the Taliban and the Afghan government, (ii) between the Taliban and the U.S. government (iii) between the U.S. and the Pakistan governments and (iv) between the Afghan and Pakistani governments including the regional and neighbouring countries. The study also found that most participants are devoted to their own political networks, and ethnical interests while negotiating with the insurgents group rather having a common agenda. 
List of Useful Abbreviations \& Explanations

$\begin{array}{llll}\text { CHAPTER } & 1 & \text { Introduction } & 6\end{array}$

CHAPTER 2 Literature Review

2.1 Policy Networks: Evolution and Concepts 9

2.2 Institutional Networks and the Policy Process 12

2.3 Uncertainty in the Networked Politics 15

2.4 Networked Politics in Afghanistan 22

2.5 The Impact of Study 25

CHAPTER 3 Methodology

3.1 Research Design $\quad 27$

3.2 Ethical Considerations 27

3.3 Sampling 28

3.4 Data Collection 29

3.5 Analysis 30

3.6 Limitations of the Study 31

CHAPTER 4 Findings \& Analysis

4.1 The High Peace Council Governing Body 32

4.2 Networked Politics: Hope and Fear 36

4.3 Challenges in Negotiating the Insurgents 40

4.4 Recommendations for Changes 43

$\begin{array}{llll}\text { CHAPTER } & 5 & \text { Conclusion } & 45\end{array}$

References 48

Annex $1 \quad$ Consent Form $\quad 52$

Annex $2 \quad$ First Contact Emails - Example 53

Annex $3 \quad$ Participant information sheet - Topic Area 54

Annex $4 \quad$ Probing Questions - Example 55

Annex 5 List of findings tables 56 


\section{LIST OF USEFUL ABBREVIATIONS \& EXPLANATIONS}

Afghan Accords Najibullah's Reconciliation Policy 1986, the Rawalpindi Accord 1989, the Peshawar Accord 1992, the Mecca Accord 1993 and the HPC 2010

Afghan Wars $\quad$ the First Anglo-Afghan War (1839-1842), Second Anglo-Afghan War (1878-1881), Third Anglo-Afghan War (1919), Soviet War in Afghanistan (1979-1989), Soviet involvement, Afghan Civil War (1989-1992), Najibullah’s Regime Collapse, Factional War between Mujahidin (1992-1996), anarchy Afghan war 'Mujahidin and Taliban' (1996-2001) Fall of Taliban and U.S. involvement (2001-present)

Conferences on Afghanistan the First Bonn (Dec 2001), Tokyo (2002), Berlin (2004), London (2006), Rome (2007) Paris (2008), Moscow (2009), the Hague (2009), London (2010) Kabul (2010), Bonn (2011), Chicago (2012), Tokyo (2012)

DDR Disarmament, Demobilisation and Reintegration of excombatants (DDR) in Afghanistan implemented after the fall of the Taliban

Green on Blue Attacks by Afghan security forces turning on their counterparts HPC High Peace Council of Afghanistan established in June 2010.

Haqani Network an insurgent group fighting against US-led NATO forces and the government of Afghanistan

Hezb-e-Islami an Afghan Islamist political party currently against US-led NATO forces and the government of Afghanistan

IED Improvised Explosive Device

ISI Inter-Services Intelligence

Junbesh A political party representing, Turkic ethnic in Afghanistan Loya Jirga Traditional Grand Council in Afghanistan holds for the purpose involving non-official politicians, elites and tribal elders in the political process.

Mujahidin Afghan fighters defeated the Soviet. The activity is called, Jihad Qawm Ethnicity, the Afghan model of power structures or political networks 


\section{CHAPTER 1}

\section{INTRODUCTION}

The feature of conflict in Afghanistan during the past 150 years has been affected by the involvement of external forces and organisations. Though the external forces had their own impact to keep Afghanistan as buffer zone to be peaceful for long period. In the result of conflicts during the last three decades the national institutions as the social fabric of the society got destroyed. After the 9/11 and involvement of the international community; there was no reason why long-lasting peace cannot be re-established.

Despite the existing challenges Afghanistan, regional and the international community together possess a vested interest in making a sustainable peace in Afghanistan. In spite of the difficult circumstances within Afghanistan and those that have been imposed upon the country and its people; the role of reconciliation has always provided a successful means and an accepted method for the settling of conflict (Rosenberg \& Nordland, 2012, pp. 2-3). The fall of Taliban was considered an historic opportunity for long-term peace and stability in the country after November 2001, which the Afghan people to seize this opportunity, they require the concerted and sustained supports by the international community after foreign involvements and internecine (Sedra, 2002, p. 4). To illustrate, Maley, et al., (2008, pp. 11-12) argue the re-constitution of a legitimate set of political arrangements is considered one of the key objectives of the post-Taliban political transition in Afghanistan. Although in conflicted country legitimacy itself is a complex idea, and historically Afghanistan has experienced lengthy periods of rule based on nonlegitimate forms of domination in the past. In other hand, Sharan \& Heathershaw describe the international state-building in Afghanistan should be considered in terms of identity politics as they have emerged in the first Bonn Agreement of 2001 reconstructing Afghanistan (Sharan \& Heathershaw, 2011). It has been argued that after a decade of the US involvement, Afghan government was successful in good and effective governance. Although in 2010 on the national reconciliation policy President Karzai addressed the nation:

'to battle terrorism, to help end violence in [Afghanistan] and ensure the safe return of [America's] sons and daughters, my government is convening a Consultative Peace Jirga - a historic forum of the Afghan people - to chart a way forward for engaging those who fight against us... I emphasize that our arms are open only to those who are not part of Al-Qaeda or any other terrorist network, 
who denounce violence and who will return to normal life respecting the Afghan constitution. We recognize that more is needed to eradicate terrorism and for our reconciliation and reintegration to success. Sincere and effective regional cooperation backed by our allies is the best guarantee for success. The Afghan people greatly value and want to strengthen their strategic partnership with the United States. We have travelled far together, but the international effort in Afghanistan still has miles to go, [and] we are not yet delivering security to large portions of the country' (Karzai, 2010, pp. 1-2).

Nevertheless, reconciliation has been a central feature of both social practices and social norms of the peoples of Afghanistan, which often replacing by force. This has been the case locally, regionally and internationally. The current instability, rather than being due to local traditions, is more the result of decades of conflict and the intentional dismantling of traditional structures in conflict, thereby leaving extremist groups to fill the socio-political and security vacuum. It is a universal condition that societies develop their own social norms and methods to resolve and settle conflict. Since communities cannot exist without the effective resolution of conflict. The paper discusses the debate on reconciliation and negotiations with the Taliban, its future prospects and the role of the HPC of Afghanistan. We argue that the very fact the conflict in its various phases has been going on for so long offers opportunities for reconciliation (Masadykov, et al., 2010) \& (Rabbani, 2012).

Furthermore the study examines the networked politics and the policy process at the HPC of Afghanistan. To illustrate in summer 2010, President Hamed Karzai unveiled a comprehensive plan for reintegration and reconciliation of a special convened Loya Jirga or (Grand Council). The purpose of this plan was to establish peaceful relations with the Taliban and including other insurgents group to reintegrate them into Afghan national institutions (Peace-Council, 2011). Though it is not the first time that Afghan leaders have sought reconciliation with the Mujahidin and now the Taliban please refer to Afghan Accord list. In 1986, President Najibullah introduced the National Reconciliation Policy, which was in operation for six years until the Mujahidin came to power in Kabul in 1992 (Najibullah, 2011, p. 1) As a result, the country turned into factional war due to lack of tolerance and agreement between different groups of Mujahidin and consequently the Taliban came into power in 1996 in Afghanistan.

Therefore the study tends to address this question; what network of contact the HPC of Afghanistan is using to strike a peace deal with the Taliban and other armed groups? 
Having said this, roles of political elites at the HPC of Afghanistan will be examined. To assess the network politics a research has been conducted to focus on the theory of networked politics and its concept including illustrating the network approach and its multi inter-organisational relations and to evaluate the characteristics of networked politics (Koppenjan \& Klijn, 2004). Considerably, the goal of the HPC is to promote peace through a political approach which will be encouraged regional and international cooperation; facilitates the political and judicial conditions for peace and reconciliation; encourage combatant foot soldiers, commanders and leaders previously siding with armed opposition and extremist groups; and to renounce violence and terrorism, and to join a constructive process of reintegration and peace (Masadykov, et al., 2010) \& (Sarwary, 2012).

The HPC is considered a tactical institution within Afghan governmental framework, and the members of HPC were selected by President Karzai after inviting sixteen hundred representatives countrywide for discussing and finding a solution to put an end point on current insecurity in Afghanistan (Peace-Council, 2011). Therefore decision was made to select seventy members amongst many politicians, abundantly were included whom agreed with the regime policies towards integrating the insurgents. During the field research it has been noticed the HPC members are following their own personal and political interests while negotiating with the Taliban (Rabbani, 2012). Importantly four political networks are going on parallel for peace and integration of the insurgent groups: first between Afghan government and the insurgents; second between the Taliban and the United States' government; third between the United States and Pakistan possibly the Saudi and Qatar governments and lastly between the Afghan and Pakistani government including some other regional and neighbouring countries. 


\section{CHAPTER 2}

\section{LITERATURE REVIEW}

This chapter tends to discuss and analyse existing literature to illustrate how this study fits into main debate and research in networked politics and the subsequent policy process. Thus, in this part it aims to explain the evolution and concepts of networked politics. It further discussed some aspects of the networked politics and the policy processes. Following this, focuses on institutional network providing evidence to discuss the roles of actors in the policy process and its set up. This chapter also discusses the policy processes; in particular, within networked politics, as whole in Afghanistan. In conclusion, the impact of this study on networked politics discourse is articulated.

\subsection{Policy Networks: Evolution and Concepts}

Researchers and intellectuals have argued it that public and private organisations in the networked arena are increasingly faced with controversies over the way and the problems they encounter should be dealt. The problem solving takes place in complex games and networks where each actor behaves strategically, guided by diverging or conflicting perceptions and rules (Koppenjan \& Klijn, 2004) \& (Isett, et al., 2011). To illustrate, the government, public and private organisations are challenged with these long-dated controversies over complex socio-problems. For instance, any decisions on the use of modern technology, the location of army base or re-structuring of public sector services have caused various conflict and debate amongst the actors, networks and policy makers (Koppenjan \& Klijn, 2004) \& (Lake \& Wong, 2007). In addition, such complexity involves the role of networks, that describes the role of 'several interdependent actors involved in delivering services' and, further the networks itself is made up of different organisations which need to exchange resources and maintain good relationship (Kickert, et al., 1997, p. xii).

Taking this into account, Rhodes (2007, p. 1244) believes that the roots of the idea of policy networks linked with both political science literature on inter-governmental relations and its analysis. The policy network examinations evaluated various dilemmas like the crucial understanding of politics in modern societies, and incorporated with specific set of actors. Hence, concept of policy network enables the policy analysts to move beyond mere description and into the more interesting field of policy research (Blom-Hansen, 1997, p. 669). In other hand, the dilemmas of networks are considered 
self-organising, self-governing, and multi-dimensional phenomenon. So-called Kickert (1993) argues that ' $[t]$ he control capacity of government is limited for a number of issues likewise; lack of legitimacy, complexity of policy processes, complexity and multitude of institutions concerned etc. Government is [the] only one of many [actors] that influences the course of events in a societal system.... Other soci[o-]institutions are, to a great extent, autonomous' (Kickert, 1993c, p. 275 cited in Walter, et al. 1997, p. xii). Nonetheless, this argument will integrate networks resist government steering, develop their own policies and mould their environments. Considering this discussion, the idea of central government is no longer supreme and political system increasingly differentiated and the unitary state and centre-less society is decreased; this recent changes affects in the polycentric state characterised by multiple actors (Kickert, et al., 1997) \& (Newman, 2003).

For example, the model of Afghan power structures is based on Qawm or ethnicity which spheres of Afghan social life. It has been argued that the ethnicity among 'Afghan stakeholders... whom Qawm or ethnic are a means of acquiring, maintaining and increasing power. But, neopatrimonialism has been identified as an important [power] principle in contemporary conflicts while analysing the conflict of Afghanistan' (Geller \& Moss, 2008, pp. 1-2). Considering this, the literature of policy network contains a rich variety of definitions and descriptions related to networks and politics (Kickert, et al., 1997, p. 6). Moreover the geographical map of these phenomena that examined around policy networks is common in the analysis of public policy in developed world (Marsh \& Smith, 2000, p. 4).

More importantly, the study of policy networks refers to 'a set of formal and informal institutional linkages between governmental and other actors structured around shared interests in public policymaking and implementation'. Arguably the theories of policy networks describes the 'organisation[al] power, relative to an element of its task environment, to the extent that the organisation has capacity [that] satisfy needs of that element and to the extent that organisation monopolies and capacity' (Rhodes, 2007, pp. 1244-5). In spite of that, the networks consider the differences between nodes. Taking this into account, specific characteristics that may privilege their likelihood of gaining links to other complex-game and, therefore, increasing their power in the network, but the network theory has largely ignored compare to politics (Lake \& Wong, 2007, pp. 2-3). From policy perspective, the policy network usually analyses, the roles of multiple actors 
depend on set of resources, goals, strategies, rules of game to regulate. Possibly, 'this [approach] is very difficult for governments to grasp, since [governments are in favour] to focus on only a handful indicators, and since few are well designed for a systematic [analysis] of the world' (Mulgan, 1997 P. xiii cited in Considine 2005).

Arguably the current understanding of policy, institutions and intervention has been improved towards examining of networks and or being in a network. To illustrate, people in today's life are no more distant from one another. For example; people can flood into each other conversation sharing a pleasant idea. Supporting this case, Mr. Zac went to school with President Clinton's daughter and Clinton knows all the world leaders. Therefore, situation can be an important opportunity for Mr. Zac to connect a good network. Having said this, the degrees of establishing a contact or relationship with the stakeholders is always not similar for all and obviously it depends on one's social ability or connection to a network (Considine, 2005, pp. 123-4).

Most importantly, tools and degrees for relationships between people and groups engaged in policy making are not equal. Elements that describe within organisational boundaries, formal mandates and interest group cleavages - now they are often said to be better understood under the rubric of network linkage, inter-organisational ties in agencies. Furthermore, the role of the new language for interaction, partnership, and reciprocal connections between actors is considered an empirical norm in the networks (Considine, 2005, p. 125).

In other word, Kenis \& Schneider (1991, p. 30) argue that 'the conjunctures and transformation of the network thinking in policy analysis which emphasis that despite the success in diffusing the policy network notion. It has not yet gained a clear, analytically distinctive meaning'. As a result, policy analysis used metaphorically to shed light on specific empirical observations. For this reason some general transformations have likewise (i) transformations in the political reality similarly in the reality of policy making as recognised by competent observers, (ii) transformations in conceptual and theoretical developments in the political sciences in general and in policy analysis in particular; and (iii) the development of methodological apparatus for structural analysis which in turn was the result of a more structural approach in the social sciences in general (Kenis \& Schneider, 1991, pp. 33-37). It is beyond the scope of this study to respond the issue indepth, nevertheless efforts have been made to address this issue to the extent possible. 


\subsection{Institutional Networks \& the Policy Process}

The previous subsection described the evolution and concepts of policy networks and in general way; they are seen as important in networked politics. Now we will narrow down our focus to concentrate on the institutional networks relates to the policy process. Thus the networked politics are regularly used in the literature to categorise the policy network from relevant institutions (Perkin \& Court, 2005, p. 14). To understand the policy networks as institutions, Blom-Hansen (1997, pp. 673-4) argues that the institutional theory illustrates on multidisciplinary enterprise in various disciplines such as politics, economics, organisations with consistent framework of analysis than an analytical idea including the notion of the organisation of political which brings a difference. So forth, the roles of institutions are very explicit, systematic complex and it is possible to identify the competing discourses.

Furthermore, Parsons (1999) states the recent growing awareness of the importance for the placing public policy in the context of institutions and the evolvement of dissatisfaction with at politics purely an executive especially in legislatures and constitutions levels. However, the prospects of policy analysis look at institutions and constitutions in favour of the policy networks in general (Parsons, 1999, pp. 323-4). Conceptually the policy network has been identified as institutions, so what can be contributed to networked politics as a whole. Perhaps to respond the issues of institution facilitate the traditional policy network analysis. As consequence it convey; a consultative policy-making environment, the depoliticisation of policy area, predictable surroundings; and the segmentation of policy areas' (Blom-Hansen, 1997, p. 679).

So far Perkin \& Court $(2005$, p. 8) illustrate that it is necessary to be wary of limiting one's analysis from the outset by relying on prescribed definitions. But, this type of characteristic can provide a useful road into the mass of information and conjecture surrounding the issue of policy networks. Nonetheless the short overview of the most common emerging terms. The issue of network institution and communities' approaches are concerned with the more relations and informal aspects of the policy-making. To illustrate, within term network 'one's seek to get advantage from the existence contacts. Although the policy network focuses on map of personal relationships, interconnectedness and dependencies on ground resources' (Parsons, 1999, p. 184). 
The overall consensus seems to be that practitioners, governmental institutions 'operates in networks frequently comp up against deep-rooted opinions about what government is or should be' (Kickert, et al., 1997, p. 59).

Overwhelmingly, the growth of both government and policy making activity the sheer range of participants has grown both wider and more complex. Subsequently the greater diversity in networked community and in policy programs geared to specific target and functions and the increase in the number of participants in policy process has meant that the network institution has been seen with a better shift in modern policy making than, other traditional models (Parsons, 1999, p. 185). Arguably this phenomenon concentrates on the behaviour of rational actor who would reach a decision within a situation of being fully informed and of complete and clear preference ranking. This type of approach is organised for political purpose. Therefore, 'the rational actor model assumes that policy processes proceed in various stage such as policy formulation, decision and implementation are based on a view in which the decision maker first analyses the problem and alternatives then makes a rational decision about which option he or she should choose' (Kickert, et al., 1997, p. 15).

To understand the importance of roles and policies play within an organisation, Frye (2007) argues that policy and procedures are very critical in an organisation's being. Therefore, let's just imagine that how an organisation without a 'well-defined' organisational policies functions. It has been argued that policies are the important requirements for organisations to be taken into consideration when determining how to go about organising its policy regime. However, it should be notified that policies affect different structural levels of an organisation (Frye, 2007, pp. 3-4).

Supporting the literature the High Peace Council have produced an advisory declaration throughout the traditional Loya Jirga two years go, with in-depth emphasis on the sacred goal for peace, should be achieved 'through mutual understanding and acceptance of each other' (Peace-Council, 2011, p. 2) Furthermore for political sphere the advisory declaration, emphasis on the needs to preserve the post-Taliban achievements with respect the country's constitution, women rights, freedom of speech includes the prevailing situation in the regional strategic cooperation with the United States of America, being a strategic ally to the people and government of Afghanistan in all sectors; defence, economic development and peace process (Peace-Council, 2011, pp. 34). As, Howlett \& Ramesh (2003, pp. 207-10) discuss the shortcoming of a public 
problem via various possible solutions but importantly by examining the success and failure the policies, examining the fundamental success and failure of a certain policy process. It involves bureaucrats and political elites within government dealing with the policies in question. It usually also involves actors from non-governmental organisations of policy subsystems as well. Indeed certain techniques are applied in policy evaluations such as cost-benefit analysis, including other measures of performance for the quality of program outputs.

However, it has been identified that network organisations reflect a qualitatively different from the governance structure than the bureaucratic hierarchies they are beginning to replace. In such situation, understanding the dynamics of the inter-organisational networks and the patterns of interaction have become urgent matters both for policy makers and those who seek to understand the policy making process and implementation (Kapucu, 2005, p. 2). To illustrate according to the World Bank \& United Nations Office on Drugs and Crime report in Afghanistan process became much more complicated, as well as it has challenged by a number of factors involved as below:

'(i) the rapidly changing nature of the political, economic and social developments occurring in the country; (ii) inadequate law enforcement capacities and widespread allegations of police corruption; (iii) the lack of inadequate public reporting such as official police accounts and statistics on the nature and extent of criminal activities; (iv) the link between criminal activities and state actors (v) widespread rumour about the extent of criminal activities and/ or who is or may be involved in them' (Doris Buddenburg; William A. Byrd, 2006, p. 192).

Although theoretical arguments have emphasis and points on the relationship exists voluntary that these are mutual or reciprocal activities, and that belonging to the network does not affect autonomy and independence of the members. However, theory and research about inter-organisational networks now exists to explain how these relationships emerge, sustain, and create value for the whole society. A particularly interesting generic type of network involves complex production relationships that benefit from being able to form and dissolve quickly. The participants therefore wish to protect themselves against opportunistic exploitation by their partners without having to suffer the delays and costs of formal means that there are some element of trust in the relationship so that post-transaction adjustments to meet the parties needs and interests 
can be quickly addressed with minimal network and inter-organisational resistance (Kapucu, 2005, p. 3).

In other hand to respond Howlett \& Ramesh (2003) illustrate on the political evaluation of government policy undertaken by just about everyone with any interest in political game. Unlike 'administrative and judicial evaluations, political evaluations are usually neither systematic nor necessarily technically sophisticated... many are inherently partisan, one-sided, and biased. Partisan political evaluations often simply attempt to label a policy a success or failure, followed by demands for continuation or change' (2003, p. 215). Despite various approaches in evaluating political policies, consultation with stakeholders of relevant policies subsystems notified a good mechanism which associates to procedural policy instruments setting up forums for public voice and establishing special consultative committees' task force for evaluation purposes. Such sorts of mechanisms examine the view of many members with institutions network. Nevertheless, stakeholders who do politics underlying policy evaluation into account see policy process on the basis of sources or ideologies and as part of a process learning in which policies develop and change on the basis of assessments of past successes and failures. For this reason, the conscious efforts are emulated successes and avoid failures (Howlett \& Ramesh, 2003, p. 216 \& 224). The different world reviews towards institutional network reflect imply different grounds for knowledge and for this purpose the paper will analyse the uncertainty in political networks.

\subsection{Uncertainty in the Networked Politics}

Koppenjan and Klijn (2004) state that the uncertainty in policy process is related to the lack of knowledge problems including the presence of various parties involved in a game - each looking for its own perceptions, objectives, and strategies (2004, p. 39). However, uncertainty deals with the complex problems in the network society and possibly it focuses on problem solving and decision making in a networked community this includes dealing with wicked societal issues as well. Taking these points into account, the organisational environment was getting much more complex. For instance a private firm consists of 'consumers [or] buyers and competitors' and many others facts involves there. For examples:

'[look at] supply companies, support companies, organisations that represent their interests, governments who impose rules, monitors and judges, consumers 
organisations, and societal interests. [Therefore] these all make demands upon products and methods of production. [Nevertheless] government organisations not only deal with political affairs, but also with citizens, target groups, interest organisations, advisory bodies, experts and judicial bodies' (Koppenjan \& Klijn, 2004, p. 3).

Apart from above, political power can be emergent property of networks, found most likely in scale free structures. That is, central (more connected) nodes can influence a network directly or indirectly and thereby shape the ends towards which nodes collectively move. Power, it turns efficient and perhaps even necessary for overcoming conflicts of interest within networks. Incorporating distributional conflicts into network theory highlights a new and broader role for political power than now recognised (Lake \& Wong, 2007, p. 2).

To examine the network theory, it has been clarified by policy analysts that networks are typically treated as varying along three related dimensions. According to Barabasi (2003, p. 111) the first dimension is the number of complexity; second the density of the network or the frequency of interactions between stakeholders and last the structure of the network, defined as the pattern of connections between stakeholders. Yes. in turn, these dimensions, and especially structure, have been used to analyse and explain the efficiency and robustness of different networks. Efficiency is the ability to transmit information across the network quickly with speed defined as the number of steps or links between actors through which a message must travel before reaching its target. Robustness, by contrast, is the ability of the network to function (i.e., transmit information) after the failure' of a node or its removal from the network (Barabasi, 2003, p. 122).

Therefore considering this discussion and referring to Afghanistan's network dilemmas, Nixon $(2008$, p. 1) argues that state building refer to efforts to increase the importance of state actors, structures and processes in governance networks. So-called it will shift governance towards government. It is the attempt to reform, build and support government institutions, making them more effective in generating the above mentioned public goods. Hence governance systems are a configuration of resources and responsibilities. There will always be interests in both generating and resisting changes to that configuration. Moreover state building is inherently political as well as technical dimensions can be compounded by the urgent imperatives of post conflict 
reconstruction which reduce the ability to tailor programs to local realities and the easier transferability of technical lessons than complex political or cultural ones. Some major theme of this shift focussed on the interaction between the political and the technical dimensions of state building (Goodhand, 2000) \& (Nixon, 2008).

Furthermore, Kickert, et al., (1997) emphasis that network model builds on the bottomup criticism, but offers a more realistic approach. Perhaps network approach considers public policy making and governance to take place in networks consisting of many players such as individuals, coalitions, bureau and organisations. Moreover, none of these stakeholders possesses 'the power to determine the strategies' of one another (Kickert, et al., 1997, p. 9). Although, the government or central actors are no longer occupying superior positions than other none-governmental organisations but they put equal efforts in this configuration.

Therefore, Rhodes (2007, pp. 1247-8) also argues that yet the conventional debate is going on between state actors. Hence, the mainstream analysis assumes the best way to look at the executive is to look at key positions and their incumbents and the executive is considered the functional authority. However, hollowing out of the state is also challenged and 'the growth of governance' reduced the ability of the core executive in order to perform effectively. For instance, it result less reliant on a command operating code and more reliant on diplomacy so called it has hollowing out the capacity of British core executives. In particular, examining the post-conflict studies the decentralisation is considered one the area where technical 'best practices' approaches come into consideration. Specifically analysing the political realities of the Afghan context there is considerable consensus internationally that decentralisation can be an appropriate way to improve local governance in many networks. Efficiency and responsiveness in the provision of public goods can improve by moving decision making and resources closer to the affected public. In spite of that decentralisation can be political (decision making) administrative (service delivery) and resource allocation. It can also take different forms: in de-concentration, responsibility and resources are moved to local level while retaining accountability relationships with the centre; devolution involves the transfer of authority to sub-national units with some autonomy and delegation involves the allocation of functions outside state structure (Nixon, 2008, pp. 3-4).

Nevertheless, Considine (2005, p. 26) refers that in such hollowing out the policy makers in modern societies have never faced more complex challenges. For this reason the 
structure and organisation of both the economy and society appears to be in a phase of profound transformation. Yet, the role of traditional institutions has undergone deep changes from which new patterns and roles are still emerging.

Whereas, Koppenjan \& Klijn (2004, pp. 45-6) argue on the importance of basic elements of the policy game. Thus, in complex societal problems such elements illustrate on involving actors, resources and dependencies and even a variety of parties such as; the individuals, groups and organisations from both public and private entities. Hence groups include major organisations such as the World Bank, or a powerful state even a political groups, including some small -scale cooperation types within and between organisations. In exploring these issues, the case of the United States presence in Afghanistan fits the literature which Liddell (2008) argues that in the past several years the U.S. has committed includes:

'[Billions] of dollars and an enormous amount of the nation's capital helping Afghanistan rebuild its country and establish a freely elected government. These successes, however, are being overshadowed by an alarming increase in the amount of illicit drugs being cultivated with Afghanistan. The effects of this rapidly escalating drug economy undermine the efforts of the fledgling Afghan government, fuelling the insurgency, and threatening the security of Afghanistan and the region' (Liddell, 2008 , p. 7).

So-called, what ties such diverse field of actors is depend upon one another. Thus, Koppenjan \& Klijn (2004, p. 46) emphasis on the dependency of springs from the fact which solve an issue, 'resources' is required that is not possessed by any one actor. It is understood that the resource associates to diverse range of formal and informal 'competencies and decision making powers'.

Further it has been notified that the 'nexus between narcotics and terrorists increases the resources available to extremists... and combined with a lack of development and governance, allow Islamic extremists to turn a poisonous ideology into a global movement' (Liddell, 2008 , p. 8).

To illustrate further the resource is considered very vital and it includes 'money, organisation, human resources' although, there are some less tangible resources as well. For example: authority, legitimacy, strategic capability, mobilisation power, etc (Koppenjan \& Klijn, 2004, p. 47). From another angle the response to problem solving 
policy problems at the subsystem level with a strong technical nature needs strategic game features in becoming engulfed in uncertainties springing from unpredictable behaviour and the complexity of the game setting. As Allison (1971) provides three following characterisation of crisis decision making:

'rational decision [supports] by discussion in the crisis team; [and] decision [taking] upon limited information and options presented on the basis of the routines of the organizations involved and [lastly] a compromise between the proposals that had been suggested in a negotiation game by parties involved in the crisis team' (Allison, 1971 cited in Koppenjan \& Klijn, 2004, p.42).

However, it has been argued that complex and difficult problems are surrounded by uncertainty. Despite the substantive complexity of these problems, there are other sources of uncertainty as well. Next majority of actors are involved and their interests are at stake, which may use different strategies in various arenas based on their own perceptions, interests and goals in order to influence the problem situation and the problem solving process (Koppenjan \& Klijn, 2004, pp. 113-4).

Post-conflict countries are particularly vulnerable to the growth of organised crime. The decline of authoritarian rule or the ending of conflict often leads to a transition to democratic governance and in many cases steps toward the establishment of market economies. This may frequently take place in the context of a legislative void, lack of transparency, lack of capacity in key government institutions, and, as a result, increased vulnerability to criminal and corrupt practices. Historical and institutional factors, such as continuing political tensions, the existence of patronage networks, non-applicability of the rule of law, and fragile civil society complicate the path to democracy and provide fragile grounds for organised criminal activities. In such circumstances law enforcement agencies often are not capable; relatively due to extensive corruption or involvement in criminal activities themselves, or lack of adequate resources or credibility, to effectively combat or prevent illegal activities. The organised crime groups, warlords, terrorist, opponent, and even members of the government may take advantage of institutional and legal weaknesses and engage in illegal activities, impeding the establishment of democratic norms and principles (Doris Buddenburg; William A. Byrd, 2006, p. 191 \& 198) \& (Schweish, 2008, pp. 1-2). 
Therefore, Koppenjan \& Klijn (2004) describe 'in addition to strategic uncertainty, there is usually institutional complexity: problems and policy games frequently cut across different networks which means that there are no unambiguous institutions that support interactions... [overall the] degree of institutional uncertainty is generated from the incompatibility of the institutions involved' (Koppenjan \& Klijn, 2004, p. 114).

Taking this into consideration thereby, theory and normative assumption of network uncertainty deals essentially with mutual adjustment and cooperation, for instance in a problematic situation it involves the interest multiple stakeholders, dependent actors, providing response to problematic queries based on values and norms, putting mutual efforts towards resources and activities. The mutual adjustment and cooperation also requires the attention of public actors in getting better results: (i) in case of resource dependency, actors use the veto powers, (ii) knowledge dispread amongst actors, and (iii) applying the go-alone strategies to optimize certain values and norms during decision making but the go-alone strategies will increase the transaction cost which means; the problem solving usually involves certain values of cooperation for effective quality. On the other hand, policy proposals face with lack of qualities encouraging actors to overcome resistance (Koppenjan \& Klijn, 2004, p. 115).

Primarily under policy games in networks the policy analysts suggest a mechanism that influences the evolution and outcome of policies. So called, to analyse the characteristic of certain processes by examining the 'deadlocks and breakthroughs which occur and the outcomes that are generated for a comprehensive examination' (Koppenjan \& Klijn, 2004, p. 115). McGann \& Sabatini (2010) have notified some independent variables likewise; cognitive causes, social causes, institutional causes, network management and external factors. To illustrate, the cognitive causes is considered as 'dialogues of the deaf' which originates as well as identifies perceptions about the nature, causes, and effects of problems including the solutions. So forth, the characteristic of this approach rely of networks' past talk, in reality it discusses on variable including the dialogue of the deaf. Generally taking decision in large project, complex system changes, and complex plan possibly results in a war of reports. The social approach emerge strategies of actors, whose resources for dealing with the problem are indispensable are uncoordinated in conflict while roads are block between actors. Thus, limited amount of coordination undermines the mutual dependencies between actors which result lack of discovering mutual interest, including uncertainty during problem solving and knowing its costs 
(McGann \& Sabatini, 2010, pp. 102-6). To support Koppenjan \& Klijn (2004, pp. 11618) state, the institutional cause 'builds a tower of Babel' when there is lack of mutual institutions. For instance building relations, rules, shared orientations and common ground reduces risk participating in policy games by providing procedures for interactions and managing conflicts. Next the network management explains the occurrence of deadlocks, breakthrough and the emergence of policy outcomes can be the presence or absence of attempts to manage policy games and the quality of these management efforts. Moreover, it has been argued that interaction between parties in complex policy games is challenged as the multiple interests, uncertainties and risk and costs are involved within the interaction. For instance an actor operates as broker, facilitator, conflicted etc., and then the chances decrease realities in decision making.

The outcome of external factor, on policy network led change perceptions, power change relations, including the institutional structure changes. Therefore, an external development factor does not always directly influence policy games within policy network. But it depends, in part, or the degree that actors see the development as opportunities (Koppenjan \& Klijn, 2004, p. 119).

In conflict transformation environment Sharan (2011, p. 1111) discusses the role of the dynamics of elite networks and patron-client relations particularly related to Afghanistan. According to Sharan 'elite networks' with the Afghan context includes top government executives, 'rule-making elites, ethno-regional factional leaders, tribal leaders, and even community elders'. So called, these elites can be structured into three groups; such as ideologically unified, consensually unified and unified (Sharan, 2011, p. 1112).

In the case of Afghanistan the elite unit, this historically much rarer, produces stable regimes, whereas a divided national elite, which is the most common type produces a series of challenges to the political process. Afghanistan is a case to elite disunity where national elites, 'deeply distrust each other; interpersonal relations do not extend across factional lines, and factions do not cooperate to contain societal divisions or to avoid political crises' (Burton \& Higley, p. 296 cited in Sharan 2011). However, the dissertation argues that elites in conflict-driven countries like Afghanistan must be analysed first and foremost with respect to their own networks and hierarchical authority structure. This following sub-section tends to explain the political networks of Afghanistan before and after Post-Taliban to a possible extent. 


\subsection{Networked Politics in Afghanistan}

Many intellectuals and practitioners are arguing that 'the challenge in network research lies in arriving at conclusions that can be generalised. Hence networks are embedded in a specific policy context, and the behaviour of network actors is defined by that particular context' (Isett, et al., 2011). Perhaps formal networks arise from diverse institutional forms that subsist on diverse funding stream that carry differing regulations and rules for implementation. Therefore, networks are thus shaped and constrained by institutional rules as well as regulatory procedures and norms that are specific to the policy arena. That is, the actions of government have been a focus of numerous critiques over the centuries' but their systematic analysis as policy science dates back only several decades (Howlett \& Ramesh, 2003, p. 20). Specifically the policy work on post-Taliban analysis the role and impact of the attempt to build formal state institutions including other various framework of analysis and examining 'the role of ethno-regional elite networks and local factions in constituting the governing regime and thus shaping the nature of state-building in Afghanistan'. In other hand according to Sharan \& Heathershaw (2011) in Afghanistan the 'ethno-politics monopolies other factionalism and this includes' (i) regional elite network that exhibit a clearly defined ethnic dimensions, and (ii) local and rural factionalism ties with sub-ethnics. Moreover, the ethno-regional networks and local linkage are the two key dimensions of informal way of politics which encountered as little more than an afterthought in most analysis of formal state-building (Sharan \& Heathershaw, 2011, p. 2) \& (Canfield, 2004, pp. 258-9).

The traditional review of power in politics is that it comes from the possession of important resources. Taking this into account, Hafner-Burton \& Montgomery (2010, pp. 1-2) illustrate, this relative possession of resources is thought to provide actors such as people, organisation and states with means of coercion or influence over others traditional practice is highly limiting, since power also comes from ties (patterns of association) that link together actors in networks. So called, it ties whether material, immaterial, determine an actor's ability to have access to, make connections between, or quickly spread resources to, other actors. An actor's relative position in a network formed by these ties provides another important source of influence over others. Power thus comes not only from the relative an actor's relative positions in networks due to enduring sets of ties to other actors and matter of fact these ties determine and actor's importance in networks. 
In the case of Afghanistan what is of supreme importance in war is to attack the enemy's strategy; next best is to disrupt his alliances; best is to attack his army. However, that one strategy rarely manages to be so successful over the other. It is also instructive to relate the strategic and tactical dynamic to the conflict (Cramer \& Goodhand, 2002 ). Considering Afghanistan's case Paddy Ashdown a British Politician (2008) states 'that strategy without tactics is the slowest route to victory. Tactics without strategy is the noise before defeat [further] an integrated approach is, in an insurgency, the only means to win the hearts and minds of the population, whilst strengthening the government institutions. These institutions draw off major sources of discontent in the civil population, amongst whom it is so important to gain support rather than driving them towards the insurgency through incremental alienation; and for this military means alone cannot suffice' (Ashdown, 2008 cited in Masadykov, et al., 2010, p. 8).

Masadykov, et al., (2010, p. 3) illustrate that the current instability in Afghanistan, rather than being due to local traditions, is more the result of decades of conflict and the intentional dismantling of traditional structures in conflict, thereby leaving extremist groups to fill the social, political and security vacuum. It is a universal condition that societies develop their own social norms and methods to resolve and settle conflict, since communities cannot exist without the effective resolution of conflict.

Nevertheless, Esser (2009, p. 3) refers to ethno spatially, arguing that 'Kabul lies on the border between Tajik, Pashtun and Hazara regions. As matter of fact, to exert political power ethnic strongmen had to leave their turf and venture into the blurred boundary'. As a result anyone that could hold Kabul also proved that they had, to some extent, wider legitimacy outside their own regions. For instance, to be recognised as a rule of Afghanistan, one had to be in possession of the Kabul. Therefore, remarks about the country's more recent history of national politics as a fight for the Kabul:

'while it may appear odd that the capital of a collapsed state could be the object of much desire, everybody has always been aware that whoever is in control of Kabul will be better positioned to claim international recognition and receive a greater share power in the event of a settlement' (Giustozzi 2003 cited in Esser, 2009, p. 3).

Historically speaking, considering the Afghan society and its religious diversity, which included Jew and Armenians in past and now only Hindus and Sikh was also a centre of 
recruitment of Muslim warriors by the rulers like Dost Mohammad for his military campaigns against Sikh tribes in the east in 1840s, and the recent Arab Muslim warriors whom supported Afghan Mujahidin defeating the Soviets in 1980s (Esser, 2009) \& (Giustozzi, 2009). In addition to ethno-politics, there were wrapped in religious discourse yet motivated relatively by the political objective of securing a cohesive sphere of influence. Yet continuing ethnic factional fighting and futile attempts of the central government to subjugate neighbouring tribes had stark consequences for the fiscal health of the national cum municipal government, thus also impacting on the city's development. As a result, much of Kabul's physical infrastructure was degenerating (Esser, 2009, p. 4).

Therefore, for the last two decades the nature of networked politics has turned to ethnicity than the parties. For example the Movement of the North in Afghanistan effectively started as a reaction towards re-centralization of power, which won a considerable degree of informal autonomy due its role in fighting the insurgency against the communist regime in 1990s by General Dostum an Uzbek not to tolerate Pashtun command like in the past. Later this alliance took the name of Junbesh representing the Turkic ethnicity which proved to be a successful political entrepreneur in Presidential election in 2004. Thus it conquered a position on the Afghan political scene, of course it happened due to Dostum's role in seizing the North movement and adopting ethnicism a key platform in the election even it changed the political formation of Northern Afghanistan in contemporary history (Giustozzi, 2005, p. 1 \& 17). Hence, the networked politics and relative game amongst the political actors are much more complex in postconflict societies as (Barfield, 2010) notified the external dependency of such society.

Furthermore, identifying the networked politics of the country, the warlord (Giustozzi, 2005) also is considered very crucial. For instance the legitimacy within this approach defined as below:

'a military leader who has political power, but little or no political legitimacy, both internally and externally. Military leaders, of course, do not completely lack legitimacy; otherwise they would not be leader. However, their legitimacy is of a military type: they are recognised as effective military commanders by their troops and most importantly by their officers or subordinate commanders. However history shows eloquently that holding political power without political legitimacy is a difficult task. The warlord, therefore, [are] depending on his 
intelligence and skills, will have to develop a form of political legitimacy or perish' (Giustozzi, 2005, p. 1).

Nonetheless, as mentioned the establishment of the Taliban Movement and its legitimacy is strong in the Southern Afghanistan where Pashtun ethnic makes majority. But they controlled the capital and major provinces in 1996. According to Dorronsoro (2005) Taliban's was policy based on single-ethnic governing Afghan and they have massacred and excluded most non-Pashtun ethnics. Such violence policy and close ties with AlQaeda a terrorist network limited the Taliban at international level and Taliban regime recognised by its three supporting countries; Pakistan, Saudi Arabia and United Arab Emirates (Dorronsoro, 2005). However, due to this relationship the Taliban regime collapsed by the United States after 9/11 attack.

So far, the fall of Taliban and the United States involvement is considered an extraordinary opportunity in establishment for democratic governments which all parties except the Taliban were the included into the political process. For the first time nationwide elections took place and billions of US Dollars have pumped in the country through the International Organisations, military operations and the some extent the aid fund has provided to Afghanistan government for direct implementations (Rosenberg \& Nordland, 2012) \& (Loyn, 2012).

More importantly the centralised model have faced with weaknesses in terms of leadership, functionality and legitimacy became apparent soon after Hamed Karzai took power, according to Barfield (2010, p. 272) argues, 'the leader of a centralised state needed to remove the existing power holders who were determined to undermine state power or make them subservient. Karzai, for all his admirable characteristics, was seen a passive, weak willed, and prone to compromise. Far from acting as a state builder, Karzai adopted a patrimonial model of the state in which its offices and resources were redistributed on a personal basis to buy the support of existing power holders or play them off against one another. Such tactics encouraged maladministration and corruption, failings that debilitated earlier Afghan government, and these became worse'.

\subsection{Impact of Study}

Despite its ideals and much commendation, networked politics and policy process in Afghanistan has not led to valued recognition and participation of political groups in the 
public sphere. An abundance of literature exists on networked politics and policy process separately. However, analyses and experiences of one within the other is fairly nuanced and thus, not as prevalent. Most of the literature that attempts to this topic does not adequately illustrate the complexities of political networks that come into play. As such, there is a greater need for studies that fuse policy networks within the post conflict societies' contexts (Cramer \& Goodhand, 2002).

This study tends to add to existing research by furthering the understanding of policy networks among various groups in a tactical institution. The study of High Peace Council aims to shed light on the complexities of diversity in active networked politics as well as the effectiveness of such initiatives as an enhancement tool. It also assesses the variation of networked politics and norms of democracy that affect involvement in the public sphere. The following chapter provides the research methods and approaches used in this study. 


\section{CHAPTER 3 \\ METHODOLOGY}

The research questions have been mentioned above; in the abstract, in the Introduction and as when they have emerged throughout the literature review.

\subsection{Research Design}

Many of the previous studies of networked politics (Hafner-Burton \& Montgomery, 2010; Rhodes, 2007; Sharan \& Heathershaw, 2011) contained a strong quantitative element and revealed important results. However, those results could not explain adequately for example, the anomalies such as; limited study conducted, direct negotiation deal with the leadership of extremists have made, post conflict countries, the exclusion of certain groups by powerful state or organisations. For this reason my empirical research is primarily qualitative in nature, using face to face semi-structured interviews, but contrary to the qualitative tradition is mainly deductive, since the theories and findings explored in the literature review are to be tested. The phenomena being studied are recent and fast changing, and so also would benefit from inductive quality (Flick, 2002) and an exploratory (Babbie, 2007) approach. Some researchers would argue that it is impossible to mix the two, but this kind of triangulation of methods is ever more frequent amongst qualitative researchers, and so justifiable (Berg, 2009) \& (Golafshani, 2003). In practice, however, because of word limitations and the task of assessing the relevance of the literature, it was not possible to develop the inductive side of the analysis to the desired degree.

It is recognised that such a micro study may not be sufficiently useful for making assumptions about the macro. However, some generalisations were able to be made. If time had allowed, a more valid study would have included many other stakeholders in order to illuminate further patterns and connections between the phenomena. Additionally, an extra element of triangulation would have been incorporated into the study in the form of textual analysis of government documents with regards to peace and integration in order to determine a clearer picture of the position of the government on the matter.

\subsection{Ethical Considerations}

Neither the area of study nor the nature of it is sensitive matters. Nevertheless, a research proposal was approved by the School for Policy Studies, through MPP course 
coordinators. Informed consent was provided by the participants through the signing of a consent form for participation in the study, and a separate one for consent to be recorded (Annex 1). Five participants refused to be named in the study. However, requests were made by some to be consulted before being directly quoted. To avoid any issues, codes have been used to refer to each interviewee, and these have been referred back to the High Peace Council (Annex 2) for the purpose of contextualising the findings. It is stressed that the interviewee responses reflect the opinions and perceptions of the individuals as well as the organisation to which they belong to. Transcripts have not been attached due to the opinion that they would be heavier than the study itself. However, if they are required to verify any matter then please do not refrain from contacting me and I will provide them - ready in presentable form.

\subsection{Sampling}

The sampling method was purposive. There seemed to be certain actors within the institution that were quite obviously involved in the phenomena being researched, important stakeholders that could reveal key information. Firstly, in order to research the impact of High Peace Council in Afghanistan, I felt it was important to choose HPC members whom presenting all major provinces including the four major ethnics; Hazara, Pashtun, Tajik and Uzbek in Afghanistan. Having language skills I used, both Dari (Persian) and Pashtu, the national languages of the country, in order to discover local knowledge also I translated all the subsequent research forms. Some of the differences between the chosen HPC that made them a potentially useful comparison have been mentioned above, however accompanied by more practical motives.

Participants make up almost all the stakeholders of the High Peace Council. Generally the stakeholders are senior in terms of their ages, political backgrounds. The interviewee list includes: former official from the Taliban regime, representatives of both the upper and the lower houses from the former and current members within the HPC framework. In addition, participants include male and female representing almost from ten provinces and more than six ethnic groups namely; Hazara, Pashtun, Tajik and Uzbek, however only ten were included in the study. Five pertinent members of HPC were unavailable to meet hence excluded. Moreover, two interviewees spoke off the record and the rest were on the record. 
The sample population was anyone from the HPC involved in; government policy making, locally high profile. Other than a carefully chosen sample thematically representing a wide variety of stakeholders perceived to be important as a result of my preliminary research, the snowball method was also used once a few of these were contacted. So that other relevant members of HPC may not as identified as important to be involved (Gilbert, 2001) this process also facilitated access to them. Gaining access in the HPC members were difficult, ten senior members were interviewed. Due to security reason the interview was conducted in the participants' places of work or at their residence.

\subsection{Data Collection}

Semi structured face to face interviews were chosen as a method of data collection since face to face interaction was the fullest condition of participating in the mind of another human being (Bryman, 2008). The interview was conducted in both Dari and Pashtu languages in order to do so technical terminologies were brush up. Each interview session was 30 minutes to 1 hour and 5 minutes, and varied with regards to depth depending on the participants' responses. With regards to the 30 minute interview, it was cut short due to an unforeseen event.

Semi-structured interviews were chosen since research methodology was to allow the researcher to assess the validity of previous research data, respond of particular questions as well as allow for new themes and relationships to be discovered (May, 2002). It was therefore important to allow for initially open discussions with probing, and then more specific questions for occasions when certain points had not been covered by the latter for each topic area. Copies of the general areas for discussion, as well as more specific questions, are visible in (Annex 4).

The interviews with members of HPC were not transcribed directly. Thus interview question were translated, as they were a number of difficulties with regards to comprehension. The transcriptions were checked for accuracy, although sections of the problematic one are sometimes questionable. Unfortunately this was the most useful interview in Pashtu nevertheless. 


\subsection{Analysis}

The analysis of the data is thematic - with regards to; the theories, findings, and some loose hypotheses that emerged from the literature review. The data was initially coded producing a long list of codes see below table. Each transcript was then coded according to each interviewee and paragraphs numbered which helped to contextualise the data once it had been fragmented during the analysis. Many captions fitted under a number of codes, and this helped to illuminate connections between themes. These codes were reassessed and reformulated where necessary and a number of categories emerged which were very much influenced by the themes being explored, but allowed for new findings to be incorporated into them.

Table $3.1 \quad$ Sample Coding

\begin{tabular}{|l|l|l|l|l|}
\hline $\begin{array}{l}\text { Interviewee } \\
\text { Code }\end{array}$ & Gender & Working information & Position & Political Background \\
\hline HPC1 & M & HPC member & Senior & Ex-Taliban \\
\hline HPC2 & M & HPC member & Senior & Technocrat \\
\hline HPC3 & M & HPC member & Senior & A Jihadi Leader \\
\hline HPC4 & M & HPC member & Senior & Member of Parliament \\
\hline HPC5 & M & HPC member & Senior & MP \& Ex Taliban \\
\hline HPC6 & F & HPC member & Senior & Senator \\
\hline HPC7 & F & HPC member & Senior & Civil Society Activist \\
\hline HPC8 & F & HPC member & Senior & Ex-Senator \\
\hline HPC9 & M & HPC member & Senior & Ex-advisor to the President \\
\hline HPC10 & M & HPC member & Senior & Politician - Ex Taliban \\
\hline
\end{tabular}




\subsection{Limitations of the Study}

There were three main limitations of this study. First, the interviews were conducted in Kabul. This city has its own characteristic in relation to politics, security and power. So, travelling to other major cities specifically to Southern was not possible due the insecurity but there are many aspects in common. The findings in this study might not be universal. The second limitation was non-random sampling was used. Participants were drawn from one institution and participated in this study were on voluntary basis. People who were not willing to participant or who were outside of Kabul (even the high profile member in the HPC) have been excluded. It is natural than human being always prefer their security and political figures hesitate to be available for interview for the critical issues. The study assumed that all participants were able to truly understand and answer the questions. In addition it was inevitable that the interviewees might give answers that they believed the interviewer wanted to hear. Despite these limitations, the findings of this study are significant for understanding multiple roles in networked politics in relation to the gender, political background, religious idea, languages, ethnicity and importantly personal interest within political networks in Afghanistan. 


\section{CHAPTER 4}

\section{FINDINGS AND ANALYSIS}

This chapter presents the results of the analysis of the interviews with the HPC members involved in networked politics as well as the policy process. This chapter is categorised in four key subsections and the data derived from the interviews were coded. Please refer to Annex 5 for elaboration.

In the first subsection of this chapter covers 'controversies over the way the problem solving takes place in networked games where actors behave strategically (Koppenjan \& Klijn, 2004); this discusses the governing framework of the HPC.

Second subsection in the light of research questions the study examines the political networks, its complexity and multitude institutions concerned (Kickert, et al., 1997), the Afghan power models (Geller \& Moss, 2008; Sharan, 2011), and relations around shared interests public policymaking and implementation (Rhodes, 2007). Also it assesses uncertainty in policy process where various stakeholders involved in politics (Koppenjan \& Klijn, 2004).

Third subsection assesses the challenges within HPC and analyses conventional debate between state actors (Rhodes, 2007) and the issues and roles of international community in Afghanistan (Liddell, 2008 ). The findings discuss the roles or regional countries (Cramer \& Goodhand, 2002), possibly the findings illustrates trust elements in reciprocal activities (Kapucu, 2005).

The last subsection addresses the research questions and the independent variables, particularly network management and external factors undermines the political power (McGann \& Sabatini, 2010; Koppenjan \& Klijn, 2004) of the HPC.

\subsection{The High Peace Council Governing Body}

Interviewees were asked about the nature of the HPC governing body and internal HPC relationships so that policy networks of the state, tendency for peace and reconciliation can be enlighten. Yet, the HPC were identified to be centralised - proving that not much has changed in this respect considering the past initiatives (Najibullah, 2011; Rabbani, 2012; Masadykov, et al., 2010). 
The HPC respondents expressed significant challenges in the tactical institution striking peace deals with relevant parties. Amongst the HPC interviewees three associated with the former Taliban regime, four associated with Post-Taliban political networks and three having neutral behaviour.

'Unfortunately it has been more than three decades that Afghan people suffer from insecurity... in the light of this a consultative council was hold in Summer 2010. The purpose of this was to bring peace among the government, Taliban and the insurgent groups. As a result the HPC was formed, which was an obvious victory for all stakeholders... thus the HPC activities have expanded to most provinces out of thirty-four provinces...' (HPC1).

'Prior to discuss about the HPC role, I want to say that peace is an immediate need for all, whether they belong to Taliban or the government. We have lost everything and destroyed the infrastructure... However, we have experienced peace for short period of time after post Taliban but it was hampered by the insurgents. Therefore, we are witness of Taliban's presence in some provinces and districts' (HPC6).

As far as the Peace is concerned, the country suffers from lack of stability since the last quarter of the twentieth century as pointed by (Goodhand, 2000). During the Soviet invasion the Afghan players fighting against the invasion were supported by various world powers. Several efforts were made in the past for national reconciliation towards peace deal with the domestic insurgencies i.e. Najibullah's Reconciliation Policy 1986, Najibullah (2011, p. 3), the Rawalpindi Accord 1989, the Peshawar Accord 1992, the Mecca Accord 1993 and 2010 HPC, hardly anyone of the past had major achievements. It is important to mention that most of the former peace deal initiatives were monopoly of power and always certain groups had been ignored and excluded.

Though the HPC implements the national reconciliation policy therefore a proper role, structure, negotiation tactics and lobby networks at local, regional and international should be determined.

'It has been several years that the US led coalition forces are in a war in Afghanistan. The presence of troops from 48 countries and the UN envoy in Afghanistan failed to bring peace. As far as I know, prior to peace talks, President Karzai visited London and the United States. He met President George W. Bush 
at his house three years ago, discussing about the peace and reintegration towards insurgent groups. President's plan was welcomed by the stakeholders including the NATO... called for Loya Jirga and nearly seventy political elites, Jihadi leaders, tribal elders, women, etc. participants were selected by the President to consult for peace... international community as well committed political and financial support to the HPC (HPC3).

In regards to HPC governing one of the interviewee (HPC2) adds:

'Let me tell you, due to insecurity we started the Afghan Peace and Consolidation Commission seven years ago led by Prof. Sebghatullah Mujadadi ... two year later a bill sent to the National Assembly and the Absolution and Compromise law was approved by the Parliament... This law provided reintegration opportunity for insurgents... this commission for more than half a decade continued several peace programs countrywide... despite of multimillion dollar expenditure and integration of more than ten thousand insurgents... this commission did not have significant contribution towards peace process and instead the instability everyday increased... Therefore in the London Conference 2010 further \$140 US dollars was donated for establishment HPC and reintegration initiative by the major donor countries' (HPC2).

About the local functions, (HPC5) illustrates, within the HPC governing body:

'[The] Executive Committee governs the HPC and this committee consists of 25 members including [the Chairman]... the council's general meeting takes place every three months, all [68] members may come at council's meeting. The Executive Committee comprising of Chairman, three deputies, two secretaries, spokesperson, one advisor and six head of the committees, leads the policy process at HPC... this committee meets once a week. Other committees are responsible in dealing with issues related to finance, international relations, religion scholars and prisons... the head of mentioned committees should work fulltime and people like myself cannot be head, as I am MP in the parliament or cabinet members do not have time to head committees too' (HPC5).

Considering the roles mentioned as above for HPC governing bodies, the effectiveness of HPC in bringing peace and instability in the Afghanistan are illustrated and following findings are driven. 
Amongst the interviewees only one respondent believed that there is lack of trust insight as it was also expressed in the literature review by (Frye, 2007) therefore it often in such circumstances makes negotiation with insurgent groups very difficult.

'Yet there is no common ground at the HPC leadership and importantly the HPC is a local player at national level... although the structure of HPC represents many elites and Jihadi leaders and etc... To bring peace, we must trust each other first...' (HPC1).

In contrast, sixty percent of the respondents have said that, HPC can bring peace and stability in the country (HPC2; HPC4; HPC6; PHC7; HPC9 \& HPC 10).

'[from policy perspective] the government has approved the Consolidation Law, it is considered a path for peace and re-integration, [primarily this law was criticised by the international community and civil society organisations and importantly by the war victims in the country] we are a legitimate government so far...' (Persian, 2010) \& (HPC2).

Furthermore, the HPC Chairman describes that we follow two dimension peace processes: first the Afghan Peace and Reintegration Program (APRP) that aims to 'reintegrate armed oppositions into the society. Those who join their communities through APRP will also be given the opportunities to work [and second] dimension is peace talks with the leadership of the armed opposition to end the ongoing conflict. The process is followed with the conditions that the armed opposition will renounce violence, accepts the Constitution of Afghanistan and cut ties with terrorist organisations' (Rabbani, 2012).

The success of the policies at HPC fully depends on the victory in other government process such as the transition of security responsibilities in 2013, the political transition in 2014 and regional cooperation (ICG, 2012). Perhaps these issues are considered for post-conflict society such as Afghanistan (Cramer \& Goodhand, 2002 ). Another important element is the long term support of the international community which plays a major role to support the country's direction towards self-reliance. For this reason thirty percent of the interviewees have said 'we are not sure' of bringing peace and stability in Afghanistan; speaking on behalf of the HPC as institution.

'Yet, the opposition have not announced their willingness for peace talk' (HPC3). 
HPC5 was referring to much more complexity, sets of stakeholders which he argues that bring peace has not only depends to Afghanistan (Barfield, 2010). 'Each country is following its own interest in [the] ground. Some countries have spent lots of money for instability of Afghanistan which they should be also ready to support the peace talks' (HPC5).

On the other hand, HPC8, emphasizes, a woman member of HPC, that it was not the job of seventy member of HPC to bring peace in the country... So-called 'peace is a need of all Afghans, regardless of their gender, age, ethnicity and parties they are related to... Therefore unwillingness of anyone can challenge this process...' (HPC8).

Given the fact that a sever diversion exists, the HPC having 'network of affiance' of government, a tool which both Kickert, et al., (1997) and Rhodes (2007) claimed to manage through using resources. Organisations aside, there were mixed opinions within the HPC including other stakeholders.

In summary, all HPC members besides being HPC representative were keen to reflect its own socio-political viewpoints as they represent one particular network within the context of Afghanistan. The theory of the devolution of power is clearly redundant unlike the government Despite this, there was uncertainty as to whether the HPC by passes its own government.

\subsection{Networked Politics: Hope and Fear}

This section examines interviewees' responses with regard to networked politics, its functionality, issues affecting that functionality, and how grass-root policy networks and policy process really are (Hafner-Burton \& Montgomery, 2010). A more normative standpoint of the interviewees in the network politics is elaborated henceforth. The HPC respondents in particular nearly all of them - voiced quite clearly their beliefs in the benefits of network politics, future directions of country including hope and fear as appropriate. This is well summarised by the passage below:

'This country has experienced 'power monopoly' in its contemporary history but the national participation of power is the best possible solution for this country and not excluding any group...'(HPC10; HPC1).

Such power model can actually exclude issues and problems from the policy making agenda. Politics was not simply what [academics] defined as the study of who gets what 
when and how but also who gets left out when and how' (Parsons, 1999, p. 134). But power monopoly is what respondents were provided great examples for country's networked politics.

'The Executive Committee of HPC takes decisions... other members are not involved in decision making process and certain HPC activities... I often hear about developments from media such as Taliban elites being removed from UN blacklist and prisoners release request from the US government...' (HPC4).

Or

'The Taliban regime was removed by the US and coalition forces and not the oppositions...' (HPC3).

Many of the respondents made very positive remarks regarding having access to resources, organizational co-operation, some commenting that they have connection much more in common with other stakeholders at regional level, than their own state... and dealing with parties at local level is much easier than dealings between countries and their institutions. Other emphasized on the international cooperation (HPC1; HPC); HPC2; HPC7). Therefore, cohesiveness of policy network is relying on resources almost all aspect policy making (Koppenjan \& Klijn, 2004). However, the case of Afghanistan deals with much uncertainty in complex networks that are illustrated in Annex 5 about the interviewees' response.

Around eighty percent of HPC members get information from HPC maybe the Secretariat, head of committee and the Executive Committee. Only respondent gets information from security office (HPC5) and one do not know (HPC6). To illustrate;

'I seek information from the HPC archive; there are sets of box files for provincial, regional as well as international levels...' (HPC1). One respondent expresses, 'to expand your question, each country which has troops in Afghanistan has intelligence too. So far, the state and the HPC receive its main information from the U.S. and NATO forces... we have our own security intelligence as well...' (HPC2).

Considering the institutional network, sixty percent of respondents stated that the HPC members were much more cooperative to each other. Whilst forty percent believe, it less cooperation was going on at the HPC. 
'President Karzai takes most of the decisions ... (HPC9) some HPC members never attended to any meeting for example Ayatollah Mohseni lives here [in Kabul] but he has never been to our meetings ... some has left the HPC due to unannounced reason; Dr. Farooq Wardak the Education Minister is one example...' (HPC2).

Prior to assess this part and the New York Times also argues that the Washington has shifted the whole 'Peace Talks' discussion to a less US-led approach and toward a more Afghan-led approach, but one that will be over a longer term. It has been argued that the American being the main player still hopes to play a behind-the scenes role. Although, divisions between the Taliban's political wing and its military commanders is considered an obstacle to serious talk and it also was very critical for the Taliban (Rosenberg \& Nordland, 2012). It has discussed in the literature review under uncertainty and resources (Liddell, 2008 ).

In contrast, Resenberg \& Nordland (2012) illustrated that Taliban are not ready to have any peace talks with President Karzai, publically. The Taliban have long derided Mr. Karzai as an American puppet, and they have steadfastly refused direct talk with Afghan Government. Therefore, this is also emphasised on dealing with uncertainties in networks. Relatively the network approach seeks problem solving and decision-making remains uncertain (Koppenjan \& Klijn, 2004), while following the outcomes of policy games at HPC.

Within the HPC organisational structure one respondent has described that 'we as HPC members meet each other every three months but we are busy in sub-committee activities. I am focusing on the relations with women in the countryside' (HPC8). Another respondent argued, at lower 'I led the public awareness and outreach activities within 31 Provincial offices under the HPC and we are trying to work at regional level in close collaboration too' (HPC3).

Above comments were meant both literally and metaphorically. However, response from another HPC did not universally indicate that this institution was the space best suited to govern, one respondent did call himself a 'fundamentalist' (HPC1). Anyhow another respondent claimed:

'I believe in mutual respect, I believe in devolution of power to the lowest level...' (HPC9). 
The existing challenge was also quoted by Western Media. In an interview of Mualavi Qalamudin, a former Taliban minister who now sits on the HPC demonstrates said, 'the Karzai administration's separate peace effort, dismissed the notion that the Taliban will never talk to the Afghan government' and such argument is considered by the U.S., resulting in abandoning hopes for peace deal with Taliban...'(Rosenberg \& Nordland, 2012).

Furthermore, interviewees were asked about the country's future direction after the withdrawal of the United States and NATO forces. Thereby fifty percent were pessimistic, ten percent was less optimistic and forty percent were very optimistic (Annex 5 provides further details).

Following passage represents 'very optimistic' approach in uncertain games.

'Overall two opinions can be seen at the HPC but I am very optimist as Afghanistan is considered a strategic partner to the U.S. and NATO. So the people of Afghanistan will have a bright future...' (HPC4).

In brief, another respondent has argued that 'looking to transition of responsibility from international community to Afghan army in 2014, I am not optimist. We may turn into anarchy and factional war' (HPC5). Another response to the same question, 'If we plan well then there is a hope in transition of power in Election as well as taking the responsibilities from international forces...' (HPC7). However, Giustozzi (2009) \& Masadykov, et al. (2010) describe 'the dynamic of civil war in the Afghanistan' which is noted in the literature.

Whereas, (Sharan, 2011) notified the complexity and dimension of ethno-politics and patron client relations in recent decades; upon such phenomena the members of HPC were selected by the President. Hence the level of threat and uncertainty directly related to 'monopoly of power and financial aid' in the country. Thus some respondents clarified:

'Some of challenge is out of the control or authority of neither the HPC nor the Afghan government...' (HPC9) subsequently 'the names of high rank Taliban should be taken out of UN and U.S. blacklists is beyond the Afghan government's authority...' (HPC1). 
Despite, there were number of issues that appeared to be connected with these uncertainties with regards to the local, regional efforts of HPC, and on assessment they most probably all fuel each other. The Guardian interviewed the Secretary General of NATO who emphasised on 'redeployment of some troops might be accelerated as green on blue attacks have hit morale and the retreat of western forces from Afghanistan could come sooner... as he conceded that the recent Taliban strategy of "green on blue" killings had been successful in sapping morale...' (Rasmussen, 2012).

In summary, there was a strong overall sense of the belief in power monopoly and the usefulness of local based efforts at the HPC, although some respondents were not so sure about the country being the ideal space for peace and stability. Additionally interviewees in the HPC seem to be serious contention between the Actors, which some suggested might be with lack of clear roles set in a constitution something which Taliban disagree with and has been discussed in the literature review (Kickert, et al., 1997; Masadykov, et al., 2010). However, any program or policy action happens with the framework of the Afghan government and the U.S. and NATO strategies, and in the case of the HPC has to follow some restrictive earmarking which some feel can stop power monopolization insight.

\subsection{Challenges in Negotiating the Insurgents}

The important 'recent challenge was considered green on blue' attacks which killed almost 50 allied troops for the last one year. Afghan security forces turning on against their trainers and counterparts had damaged the relationship between the international forces and the Afghan police and military. As mentioned it can reduce the number of foreign troops, and strengthen the oppositions (Rasmussen, 2012). This undermines the strategic of network management publically (Kickert, et al., 1997).

Nevertheless respondents were asked about their perceptions of the challenge towards peace, elements that supports the oppositions group and amount of time needed for peace. All the interviewees had expressed different opinions. In regards to challenge towards peace deal thirty percent of respondents said: disagreement amongst the insurgents group and fifty percent claimed lack of regional cooperation specifically the neighbouring countries. Only twenty percent of respondents claimed 'disagreement and mistrust amongst the HPC members as main institution for peace and reintegration of 
insurgents groups' (HPC1; HPC6). As such phenomena have discussed within the new institutional perspective on policy network by (Blom-Hansen, 1997).

Therefore, most of respondents were political elites and they are informed about state resources also they were aware of the direct impact of state resources within a tactical institution. Such issues were highlighted by (Mulgan, 1997; Considine 2005).

Fifty percent of the respondents (Annex 5) believed the foreign countries support the insurgents group; such dilemmas discussed dealing with wicked problems and reducing uncertainty (Koppenjan \& Klijn, 2004). To illustrate interviewee's statement, 'during the last three decades all political networks have received foreign assistance and still both the government and oppositions are receiving conditional supports and this apply for Taliban's as well...' (HPC1). Universally the respondents named Pakistan's government and it military wings [army \& ISI] three mentioned Iran; two have mentioned Arabic countries but mainly the religious schools and business companies (HPC5; HPC9). This is nonetheless understandable and explainable since history of conflict and government have very little direct contact with the leadership of the insurgents but efforts towards the regional and international community were considered very vital (HPC4; HPC3; HPC1; HPC6).

In addition three respondents claimed the insurgents have the people's support but they were not denying the influence of neighbouring and Islamic counties on Taliban, Hezbe-Islami and Haqani Network (HPC1; HPC3; HPC8).

Therefore, all HPC respondents were probably not aware of the direct impact of the regional supports or cooperation as they were not involved in the political process though one respondent mentioned:

'We are a legitimate government and should follow two policies (i) negotiation and reconciliation; and (ii) use force against the insurgent groups until they come down or accept the peace and re-integration' (HPC4).

Two respondents stated, 'still the leadership of Taliban and Haqani Network rejected the peace talks and however we have sent messages to insurgents many times...' (HPC3; HPC8). Unfortunately, none of the messages contributed towards receiving positive response from Taliban, for instance couple of HPC's proposal of direct talks to the 
Taliban was rebuffed that reconciliation with corrupt government lacked response (Rosenberg \& Nordland, 2012).

In spite of that, Taliban's policy was not uncertain towards peace deal. Perhaps they were responsible for the assassinations of former chairman of the HPC (Farhad, 2011) and Head of Prison Affairs Committee (Farhad, 2012) for the last two years. However two interviewees referred to power monopoly by the Taliban in one hand and the Afghan government on other which challenges the available state resources including the amount of time (HPC7; HPC9).

'Power monopoly assumption has linked to internal and external aspects if we take Afghanistan's case into account...' (HPC9).

For this reason, forty percent of respondents argued that HPC need long time to succeed. Thirty percent were mentioned that the reconciliation depends on the Taliban [including all other insurgents], although the remaining thirty percent of respondents argued, Peace and stability really depend on both; the government and the insurgents to share state resources (Annex 5).

The interviewees were asked to respond what number of insurgents welcomed the peace process; and how many were Taliban. Thus sixty percent of respondents confirmed that 5000 insurgents joint the government but forty percent of interviewees did not confirm above figures. Please refer to Annex 5, Table No. 5 for further information.

There were few Taliban who welcomed the reintegration program, however the high profile Taliban' did not join the process; and seventy percent responds the second question under challenges (Annex5). Thirty percent of respondents did not right information to confirm the question. To address these challenges, majority of respondents argued it is better to rely on regional and international cooperation as each control either resources or force in Afghanistan (HPC1; HPC4; HPC5; HPC6; HPC8; HPC9) and forty percent suggested that we should revise our policies at regional level dealing with insurgents (HPC2; HPC3; HPC7; HPC10) two examples support each:

We have travelled many times to Pakistan, Saudi Arabia, Turkey, Turkmenistan, Iran, Qatar and Japan. For instance, delegation had in depth discussion government; military wing [army \& ISI] and religious scholars also we met the Taliban representatives in Japan recently' (HPC3; HPC5). 
Four respondents agreed (HPC2; HPC3; HPC7; HPC10) with below passage:

'The Saudi influence certain countries and groups. Obviously we want Saudis to put much more pressures on both; Pakistan and the insurgents...'

The HPC approach was not actually identified as the most effective formal way to influence insurgents' positions other than through the regional cooperation. Domestic efforts were a good achievement for HPC.

\subsection{Recommendations for Changes}

Moreover, respondents had messages to their counterparts, national stakeholders, insurgents as well as the international community which table No. 5 under Annex 5 illustrate further.

To summarise, fifty percent of interviewees prioritised national interest and rest fifty percent have illustrated on mutual respect as political elites. Also fifty percent of respondents agreed 'the international community and its role are vital for Afghanistan' (HPC2; HPC5; HPC6; HPC8; HPC9). Thirty percent believed, Afghan voice and political networks should be considered internationally (HPC4; HPC7; HPC10). Although twenty percent argued that international community supports one side as 'the Taliban are excluded from political process' (HPC1; HPC3).

Importantly considering the resources in networked politics the interviewees' had called the U.S-led NATO:

'The mission has not accomplished. The mission has not done and the enemy has not death. [So] you call your exit anything; you can give it any title. For as long as the mission is not done, it means retreated' (HPC4; HPC6; HPC8; HPC10).

But, twenty percent of respondents mentioned 'lack of foreign policy in Afghanistan' (HPC5; HPC9) which is vital as (Frye, 2007) illustrate on policies for 'organisation and government'. Another, twenty percent requested all parties to observe the international convention during the fighting (HPC1; HPC7). HPC2 said, "we should strengthen the Afghan army'. Lastly another said Taliban must leave fight and stands for election if they have public supports (HPC3).

In summary, the Afghan government is key elements that affect the HPC policy. The networked politics seems to be fruitful is influencing the regional informally through 
building diplomatic relations with the policy makers and stakeholders are vital. The power of lobbying through partnerships was deemed strong. 


\section{CHAPTER 5}

\section{CONCLUSION}

The HPC and its efforts through political networks have significant challenges ahead for achieving a long lasting peace and sustainable development in Afghanistan. This study examined the effects of networked politics at the HPC of Afghanistan by evaluating the related policies and experiences of political elites who were involved in the political and policy process of this institution.

For this reason, the study examined related policy documents and the generalisation of individual reasons for establishment of institution such as High Peace Council where the country is suffering from insecurity. It is also based on reviews of existing researches, especially researches of post conflicted countries. This study conducted interviews with political elites to find out and examine real influences of policies can be revealed by assessing these testimonies. Although ten interviewees are not enough to represent the entire networked politics within HPC, the research outcomes can still be used as meaningful advice and opinions for networked politics and the policy process in Afghanistan.

This study actually calls into question claims that there has been a real devolution of power in post conflict country as advocated by the theory of (Rhodes, 2007; HafnerBurton \& Montgomery, 2010). Although on the surface it gives the impression of a dispersion of powers to stakeholders since a number of autonomous agencies or organisations such as Loya Jirga, U.S. and NATO forces, civil societies are cooperative to each other publically. What this has in fact resulted in is the shifting of responsibility to HPC as tactical institution even though has no real authority. In reality, such agency is still very much puppets of government or possibly a tool to put much political pressure on the unarmed opposition's parties.

The key conclusion, therefore is that the examination of political networks and other stakeholders in the post conflict is completely influential as (Goodhand, 2000; Giustozzi, 2009 Barfield, 2010) mentioned. The HPC is not redundant in the process of strike a peace deal domestically but it fully depends on the regional and international efforts as HPC receives financial aid, promises and possibly threat from its neighbouring countries that supports the insurgents. It is merely supplement by other actors in more strategic complex games. The norm at centrality of inter-governmental relations is indeed too 
often ignored by multiple players which are confusing the HPC insists on domestic, regional and international participation in agenda setting, policy negotiations and decision making. There was evidence from the interviews that HPC has been unable to deal with insurgents' leaderships in particular the leadership of the Taliban and Haqani network. However, it claimed that Hezb-e-Islami leadership Gul Budin Hekmatyar welcomed the peace process to a certain extent. Basically this party divided into three subdivisions and two divisions had joint the government under the leadership of Abdul Hadi Arghandiwal, the Minister for Economy and Sabawoon, an advisor to President. Such issues mentioned by (Barfield, 2010).

It might consider strike a bargain recession may be evidence enough, but in other hand it has argued that due to state intervention the HPC policy process was challenged; lack of well-defined foreign policy towards neighbouring countries; in particular Pakistan and Iran undermine the peace deal. Anyhow, this is merely speculation in networked politics at the HPC.

The study considered that the HPC publicises the government's objectives for peace negotiations to ensure that they have public support. Nevertheless the study also found four different stakeholders putting efforts are parallel ongoing negotiations within the umbrella of the Afghan peace and reintegration program: (i) between the Taliban and the Afghan government, (ii) between the Taliban and the U.S. government, (iii) between the U.S. and the Pakistan governments, and (iv) between the Afghan and Pakistani governments. Therefore it makes difficult for the HPC finding common objectives from such networks to determine the conditions for peace negotiations and reconciliation would be keys to gain transparency, credibility and mass support for a lasting peace in Afghanistan as political network and complexity exist (Kickert, et al., 1997; Najibullah, 2011; Rabbani, 2012).

Most importantly the country receives its core budgets including the entire development budget through the international aid (Mastoor, 2011). For this reason networked politics and the government may be failed if the fund disappears. In order to succeed the HPC and the government as organisations and relatively networked politics have two challenges ahead; firstly, to be ready to assume responsibility for security when U.S. \& NATO forces withdraw in 2014. Secondly, to organise a credible presidential election and transfer of power to new successor in the same year considered vital (ICG, 2012). 
Lastly, this study could have been a better textual analysis of relevant documents with regards to networked politics and policy process in order to attempt to determine the true position of the HPC on the matter - this would add validity to the claimed goal. A wider study, incorporating in-depth examination would also improve the generalisability of the claims that were made. 


\section{REFERENCES}

Babbie, E., 2007. The Practice of Social Research. 11th ed. Toronto: Thomson Wadsworth. Barabasi, A.-L., 2003. Linked: How Everything is Connected to Everything Else and What it Means for Business, Science, and Everyday Life. 1st ed. New York: Plume.

Barfield, T., 2010. Afghanistan: A Cultural and Political History. 9th ed. Princeton University Press: Princeton.

Berg, B. L., 2009. Qualitative Research Methods: For the Social Sciences. 7th ed. Boston: Allyn \& Bacon.

Blom-Hansen, J., 1997. A 'New Institutional' Perspective on Policy Network. Public Administration, 75(1), pp. 669-693.

Bryman, A., 2008. Social Resseach Methods. 3rd ed. Oxford: Oxford University Press.

Canfield, R. L., 2004. New Trends among the Hazaras: From "The Amity of Wolves" to "The Practice of Brotherhood". Iran Studies, 37(2), pp. 241-263.

Considine, M., 2005. Making Public Policy: Institutions, Actors, Strategies. 1st ed. Cambridge: Polity Press.

Cramer, C. \& Goodhand, J., 2002 . The Post-Conflict Challenge in Afghanistan. Development and Change, 35(5), pp. 885-909.

Doris Buddenburg; William A. Byrd, 2006. Afghanistan's Durg Industry: Structure, Functioning, Dynamics, and Implifications for Counter-Narcotics Policy, New York: World Bank \& United Nations Office on Drugs and Crime.

Dorronsoro, G., 2005. Revolution Unending: Afghanistan 1979 to the Present. 1st ed. London: Hurst \& Co. Ltd.

Esser, D. E., 2009. Who Governs Kabul? Explaining Urban Politics in a Post-War Capital City, London: Development Studies Institute, LSE.

Farhad, F., 2011. Death of a Peace Ambassador, Kabul: High Peace Council; Newsletter.

Farhad, F., 2012. Death of Mawlavi Arsala Rahmani, Kabul: High Peace Council.

Flick, U., 2002. An introduction to Qualitative Research. 2nd ed. London: Sage Publication.

Frye, D. W., 2007. Network Security Policies and Procedures. 1st ed. Alexandria: Springer.

Geller, A. \& Moss, S., 2008. Growing Qawm: An Evidence-driven declarative Model of Afghan Power Structures. Advances in Complex Systems, 5 February, 11(2), pp. 321-335.

Gilbert, N., 2001. Researching Social Life. 2nd ed. London: Sage Publication. 
Giustozzi, A., 2005. The Ethnicisation of an Afghan Faction: Junbesh-i-Milli from its Origins to the Presidential Election, London: Development Studies Institute, LSE .

Giustozzi, A., 2009. The Eye of the Storm: Cities in the Vortex of Afghanistan's Civil Wars, London: Development Studies Institute, LSE.

Golafshani, N., 2003. Understanding Reliability and Validity in Qualitative Research. The Qualitative Report, 8(4), pp. 597-607.

Goodhand, J., 2000. From Holy War to Opium War? A Case Study of the Opium Economy in North Eastern Afghanistan. Central Asian Survey, 19(2), pp. 265-280.

Hafner-Burton, E. M. \& Montgomery, A. H., 2010. Centrality in Politics: How Networks Confer Power. Illinois, Southern Illinois University Carbondale.

Howlett, M. \& Ramesh, M., 2003. Studying Public Policy: policy cycles and policy subsystems. 2nd ed. Oxford: Oxoford University Press.

ICG, 2012. International Crisis Group. [Online]

Available at: http://www.crisisgroup.org/en/regions/asia/south-asia/afghanistan/236afghanistan-the-long-hard-road-to-the-2014-transition.aspx [Accessed 910 2012].

Isett, K. R. et al., 2011. Networks in Public Administration Scholarship: Understanding Where We Are and Where we need to Go. Public Administration Research and Theory, 2(3), p. i157i173.

Kapucu, N., 2005. Interorganizational Coordination in Dynamic Context: Networks in Emergency Response Management. Connections, 26(2), pp. 33-48.

Karzai, H., 2010. High Peace Council. [Online]

Available at: http://www.hpc.org.af/english/index.php/articles/14-afghanistan-appreciatesits-partnership-with-the-us

[Accessed 2009 2012].

Kenis, P. \& Schneider, V., 1991. Policy Networks and Policy Analysis: Scrutinizing a New Analytical Toolbox. [Online]

Available at: http://home.comcast.net/ alan.clayton-

matthews/pp704/Kenis and Schneider.pdf

[Accessed 2808 2012].

Kickert, W. J., Klijn, E.-H. \& F.M.Koppenjan, J., 1997. Managing Complex Networks: Strategies for the Public Sector. 1st ed. London: Sage Publication.

Koppenjan, J. \& Klijn, E.-H., 2004. Managing Uncertainties in Networks. 1st ed. London: Routledge.

Lake, D. A. \& Wong, W., 2007. The Politics of Networks: Interests, Power, and Human Rights Norms. [Online] 
Available at: $\underline{\text { http://ssrn.com/abstract }=1004199}$

[Accessed 02 July 2012].

Liddell, D. J., 2008 . Drugs in Afghanistan: the Challenges with Implementing U.S Strategy, Pennsylvania: U.S. Army War College.

Loyn, D., 2012. BBC. [Online]

Available at: http://www.bbc.co.uk/news/world-asia-18758148

[Accessed 2609 2012].

Maley, W. et al., 2008. State Building, Security, and Social Change in Afghanistan: Reflections on a Survey of the Afghan People. 1st ed. Kabul : The Asia Foundation .

Marsh, D. \& Smith, M., 2000. Understanding Policy Networks: towards a Dialectical Approach. Political Studies Association, 48(1), pp. 4-21.

Masadykov, T., Giustozzi, A. \& Page, J. M., 2010. Negotiating with the Taliban: Toward a solution for the Afghan conflict, London: LSE London.

Mastoor, M. M., 2011. Annual Fiscal Report, Kabul: Ministry of Finance.

May, T., 2002. Social Research: Issues, methods and process. 3rd ed. Philadelphia: Open University Press.

McGann, J. G. \& Sabatini, R., 2010. Global Think Tanks. 1st ed. New York : Routledge.

Najibullah, H., 2011. Afghan Attempts At Peace and Reconciliation 1986 \& 2010: A Compararison, New Delhi: Delhi Policy Group.

Newman, M. E. J., 2003. The Structure and Function of Complex Networks. Society for Industrial and Applied Mathematics, 45(2), pp. 167-256.

Nixon, H., 2008. Subnational State-Building in Afghanistan, Kabul : Afghanistan Research \& Evaluation Unit .

Parsons, W., 1999. Public Policy: An introduction to the theory and practice of policy analysis. 2nd ed. Cheltenham: Edward Elgar.

Peace-Council, H., 2011. High Peace Council of Afghanistan. [Online]

Available at: http://www.hpc.org.af/english

[Accessed 08 July 2012].

Perkin, E. \& Court, J., 2005. Networks and Policy Processes in International Development: $A$ literature review, London: Overseas Development Institute.

Persian, B., 2010. A critics on Consoldation Law of Afghanistan (Eteraz bar alaihee Qanoon Afe-Omomi Afghanistan). [Online]

Available at:

http://www.bbc.co.uk/persian/afghanistan/2010/05/100509 k01 af protest.shtml

[Accessed 0210 2012]. 
Rabbani, S., 2012. Tokyo Conference Brings Hope to Afghanistan's Future, Kabul: High Peace Council of Aghanistan.

Rasmussen, A. F., 2012. Guardian. [Online]

Available at: http://www.guardian.co.uk/world/2012/oct/01/nato-forces-afghanistan-earlyretreat

[Accessed 510 2012].

Rhodes, R., 2007. Understanding Governance: Ten years on. Organization Studies, 5 July, pp. 1243-1264.

Rosenberg, M. \& Nordland, R., 2012. The New York Times. [Online]

Available at: http://www.nytimes.com/2012/10/02/world/asia/us-scales-back-plans-forafghan-peace.html?pagewanted=all \& $r=0$

[Accessed 0310 2012].

Sarwary, B., 2012. Why Taliban are so strong in Afghanistan, London: BBC.

Schweish, T., 2008. Is Afghanistan a Nacro-State?, New York: The New York Times.

Sedra, M., 2002. Challenging the Warlords Culture: Security Sector Reform in Post-Taliban Afghanistan. [Online]

Available at: www.bicc.de

[Accessed 2908 2012].

Sharan, T., 2011. The Dynamics of Elite Networks and Patron-Client Relations in Afghanistan. Europe-Asia Studies, 63(6), pp. 1109-1127.

Sharan, T. \& Heathershaw, J., 2011. Identity Politics and Statebuilding in Post-Bonn Afghanistan: The 2009 Presidential Election. Ethnopolitics, 10(3), pp. 297-319. 


\section{ANNEX 1 \\ Participant Consent Form}

An examination of networked politics and the policy process at the High Peace Council of Afghanistan

Student Research: 711018 (example)

\section{Please tick box}

Have you read the information sheet?

Have you had an opportunity to ask questions about the project?

Have you received enough information about the project?

Do you understand that you are free to withdraw from the project at any time, without giving reason?

Do you agree to participate in the project?

Do you agree to allow me to tape record your interview?

Name of participant

Name of person taking consent date

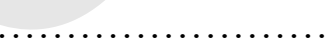

date signature

signature

\section{Contact for further information}

Ifyou need any further information, please contact my supervisor Sarah Ayres (who is supervising my dissertation) School for Policy Studies, University of Bristol, 8 Priory Road, Bristol BS8 1TZ

Tel: 01179546762 


\section{ANNEX 2 \\ FIRST CONTACT EMAIL: EXAMPLE}

Dear Mr/Ms X:

I am studying for a Master in Public Policy at the University of Bristol and am researching on the Networked politics and the policy process at the High Peace Council (HPC) of Afghanistan.

It seems that this is an area demonstrating great diversity as the HPC members are coming from different political backgrounds, their knowledge and experiences is highly important. For this reason that I want examine the policy networks of the HPC. In particular addressing what network the High Peace Council of Afghanistan is using to strike a peace deals with the Taliban and other armed groups? Supporting the literature and as well as the case study.

I was hoping that you would be so kind as to allow me to meet with you and ask you a few questions about this topic since your role in ...................will most certainly have provided you with an illuminating understanding of the workings of this phenomenon from ...............point of view. I will contact you by telephone in few days to ask you whether you will consider this meeting.

Yours sincerely

Reza Kateb

NOTE: the Dari (Persian) translation of above letter has sent to both the participant and the HPC secretariat. 
ANNEX 3

\section{Participant Information Sheet}

Titles: An examination of networked Politics and the Policy Process at the High Peace Council of Afghanistan.

Student Researcher: Reza Kateb (example)

You are being invited to take part in a research project. The following information outlines why the research is being conducted and what it will involve. Please contact me for further details if anything is unclear.

I am a student studying for the MSc in Public Policy in the School for Policy Studies, University of Bristol. As part of the degree I am required to complete a research project. I have chosen to do an examination of (opportunities and challenges) the networked politics and the policy process at the High Peace Council of Afghanistan. I am seeking lessons from your various experiences in terms of policy networks that HPC is using to strike a peace deal with the Taliban including other armed groups.

Having read this information, if you are willing to take part in the project I will arrange a convenient time to interview you at your place of work. You will have the opportunity to ask questions before the interview and I will ask you to sign a form saying that you understand what the study is about and that you have agreed to take part. After you have given your consent, I will interview you for no more than an hour and record it if you agree.

It is entirely your decision whether or not to take part and if you do agree, you are still free to stop at any time without giving a reason.

All information collected will be kept strictly confidential unless I deem that the participant is at risk of significant harm. Information will be stored anonymously and will only be identified by a reference number. When the findings are presented in my dissertation they will be anonymous and all details which could jeopardise the anonymity of a participant will be withheld.

If you need any further information please contact my supervisor Sarah Ayres who is supervising my project:

School for Policy Studies, University of Bristol, 8 Priory Road, Bristol, BS8 1TZ

Tel: + 44(0) 1179546762

Or myself, Reza Kateb:

reza.kateb.2011@my.bristol.ac.uk, Mob: 0799557221 \& 0785715129 


\section{ANNEX 4 \\ Topic guide of interviews and questions}

\section{Introduction}

1) The objective and introduction of the research/dissertation

2) Reaffirming confidentiality

3) Asking permission to the recording

4) Explaining the Participant about the Information Sheet and asking for the consent

5) Briefly introduction about the networked politics and policy process in the capacity of student.

\section{Topics}

1) It has been more than three decades that the people of Afghanistan suffer from war and conflict. However, after the US led intervention the 'insecurity' is considered a serious challenge towards state building in the country. Specifically it has been a couple of years that the Taliban is against the reconstruction process and state building this may includes some other factors such as drug economy. Nevertheless, the High Peace Council is still a mirror for hope from an Afghan perspective. Could you tell me about the institutional structures and process of the High Peace Council?

2) Can the High Peace Council bring peace and stability in Afghanistan?

3) Where and how do you go and gather the information first?

4) How do you evaluate the HPC colleagues in this process?

5) What do you think about the future of the country especially after the withdrawal of the US-led NATO forces from the Afghanistan, after December 2014?

6) What is the main challenge in bringing peace and reconciliation in Afghanistan?

7) How long might it take to reintegrate the Taliban possibly?

8) Who is behind the Taliban including other armed oppositions in Afghanistan?

9) The Taliban, Haqani network and Hezb-e- Islami leadership refuse Government's effort and do you agree with this matter?

10) So far how many Taliban militants have joined the High Peace Council?

11) Were they Taliban members only?

12) It says that foreign Taliban is considered a serious challenge so what is the council's position towards the foreign armed militants in the country, and have you contacted their country of origins?

13) What is your advice to armed militant groups including the Taliban?

14) What do you think about the rule of international community in the peace process?

Closing: Is there anything else you would like to add? 
Annex 5 (Table No.1)

Reponses whether the HPC bring Peace \& Stability in Afghanistan

\begin{tabular}{|l|l|l|}
\hline Interviewee Code & Gender & $\begin{array}{l}\text { Question HPC bring } \\
\text { peace \& stability }\end{array}$ \\
\hline HPC1 & M & No \\
\hline HPC2 & M & Yes \\
\hline HPC3 & M & Not sure \\
\hline HPC4 & M & Yes \\
\hline HPC6 & M & Not sure \\
\hline HPC7 & F & Yes \\
\hline HPC8 & F & Yes \\
\hline HPC9 & F & Not sure \\
\hline HPC10 & M & Yes \\
\hline
\end{tabular}


ANNEX 5 (Table No. 2)

Responses to below three questions (Cooperation, Hope and Fear)

\begin{tabular}{|l|l|l|l|l|}
\hline $\begin{array}{l}\text { Interviewee } \\
\text { Code }\end{array}$ & Gender & $\begin{array}{l}\text { Access to } \\
\text { information }\end{array}$ & $\begin{array}{l}\text { Level of } \\
\text { Cooperation at } \\
\text { HPC }\end{array}$ & $\begin{array}{l}\text { Country's } \\
\text { future } \\
\text { direction }\end{array}$ \\
\hline HPC1 & M & HPC Executive & Much Cooperation & Pessimistic \\
\hline HPC2 & M & HPC Executive & Much Cooperation & Very optimistic \\
\hline HPC4 & M & HPC Executive & Less Cooperation & Very optimistic \\
\hline HPC5 & M & Security Office & Less Cooperation & Pessimistic \\
\hline HPC6 & F & Don't Know & Less Cooperation & Pessimistic \\
\hline HPC7 & F & HPC Executive & Much Cooperation & Pessimistic \\
\hline HPC8 & F & HPC Executive & Much Cooperation & Pessimistic \\
\hline HPC9 & M & HPC Executive & Less Cooperation & Less optimistic \\
\hline HPC10 & M & HPC Executive & Much Cooperation & Very optimistic \\
\hline
\end{tabular}


ANNEX 5 (Table No. 3)

Responses to below three questions (Challenges)

\begin{tabular}{|c|c|c|c|c|}
\hline Code & Gender & $\begin{array}{l}\text { Challenge towards } \\
\text { Peace }\end{array}$ & $\begin{array}{l}\text { Who supports the } \\
\text { insurgent groups }\end{array}$ & $\begin{array}{l}\text { Time required for } \\
\text { peace deal }\end{array}$ \\
\hline HPC1 & $\mathrm{M}$ & Disagreement at HPC & $\begin{array}{l}\text { Foreign element and } \\
\text { people }\end{array}$ & Depend on both sides \\
\hline HPC2 & $\mathrm{M}$ & Regional & Foreign element & $\begin{array}{l}\text { Depend on insurgents } \\
\& \text { regional players }\end{array}$ \\
\hline HPC3 & $\mathrm{M}$ & Regional & $\begin{array}{l}\text { Foreign element and } \\
\text { people }\end{array}$ & Depend on both sides \\
\hline HPC4 & $\mathrm{M}$ & $\begin{array}{l}\text { disagreement among } \\
\text { Taliban }\end{array}$ & Foreign element & Long time \\
\hline HPC5 & $\mathrm{M}$ & Regional & Foreign element & Long time \\
\hline HPC6 & $\mathrm{F}$ & $\begin{array}{l}\text { disagreement among } \\
\text { Taliban }\end{array}$ & Foreign element & Long time \\
\hline HPC7 & $\mathrm{F}$ & Regional & Power monopoly & Long time \\
\hline HPC8 & $\mathrm{F}$ & Disagreement at HPC & $\begin{array}{l}\text { Foreign element and } \\
\text { people }\end{array}$ & $\begin{array}{l}\text { Depend on insurgents } \\
\text { \& regional players }\end{array}$ \\
\hline HPC9 & $\mathrm{M}$ & $\begin{array}{l}\text { disagreement among } \\
\text { Taliban }\end{array}$ & Power monopoly & Depend on both sides \\
\hline HPC10 & $\mathrm{M}$ & Regional & Foreign element & $\begin{array}{l}\text { Depend on insurgents } \\
\text { \& regional players }\end{array}$ \\
\hline
\end{tabular}


ANNEX 5 (Table No. 4)

Responses to below three questions (Opportunities)

\begin{tabular}{|c|c|c|c|c|}
\hline Code & Gender & $\begin{array}{l}\text { Figures welcomed } \\
\text { the peace process }\end{array}$ & Were Taliban welcomed & $\begin{array}{l}\text { Policy should } \\
\text { be applied }\end{array}$ \\
\hline HPC1 & $\mathrm{M}$ & Around 5000 & $\begin{array}{l}\text { Few Taliban and not } \\
\text { high profile Taliban }\end{array}$ & $\begin{array}{l}\text { International \& } \\
\text { Regional }\end{array}$ \\
\hline HPC2 & $\mathrm{M}$ & Around 5000 & $\begin{array}{l}\text { Few Taliban and not } \\
\text { high profile Taliban }\end{array}$ & Regional \\
\hline HPC3 & $\mathrm{M}$ & Around 5000 & $\begin{array}{l}\text { Few Taliban and not } \\
\text { high profile Taliban }\end{array}$ & Regional \\
\hline HPC4 & $\mathrm{M}$ & Around 5000 & $\begin{array}{l}\text { Few Taliban and not } \\
\text { high profile Taliban }\end{array}$ & $\begin{array}{l}\text { International \& } \\
\text { Regional }\end{array}$ \\
\hline HPC5 & $\mathrm{M}$ & Few joint & $\begin{array}{l}\text { Few Taliban and not } \\
\text { high profile Taliban }\end{array}$ & $\begin{array}{l}\text { International \& } \\
\text { Regional }\end{array}$ \\
\hline HPC6 & $\mathrm{F}$ & Few joint & $\begin{array}{l}\text { Few Taliban and not } \\
\text { high profile Taliban }\end{array}$ & $\begin{array}{l}\text { International \& } \\
\text { Regional }\end{array}$ \\
\hline HPC7 & $\mathrm{F}$ & Around 5000 & $\begin{array}{l}\text { Few Taliban and not } \\
\text { high profile Taliban }\end{array}$ & Regional \\
\hline HPC8 & $\mathrm{F}$ & Few joint & Don't know & $\begin{array}{l}\text { International \& } \\
\text { Regional }\end{array}$ \\
\hline HPC9 & $\mathrm{M}$ & Around 5000 & Don't know & $\begin{array}{l}\text { International \& } \\
\text { Regional }\end{array}$ \\
\hline HPC10 & $\mathrm{M}$ & Few joint & Don't know & Regional \\
\hline
\end{tabular}


ANNEX 5 (Table No. 5)

Responses to below three questions (Recommendations for Changes)

\begin{tabular}{|c|c|c|c|c|}
\hline Code & Gender & To Consider & Roles Assessment & Recommendation \\
\hline HPC1 & $\mathrm{M}$ & National interest & $\begin{array}{l}\text { International force } \\
\text { supports one side }\end{array}$ & $\begin{array}{l}\text { Int. community respect } \\
\text { the Int. conventions }\end{array}$ \\
\hline HPC2 & $\mathrm{M}$ & National interest & $\begin{array}{l}\text { International community } \\
\text { supports is highly vital }\end{array}$ & $\begin{array}{l}\text { we should focus on } \\
\text { Afghan army }\end{array}$ \\
\hline HPC3 & $\mathrm{M}$ & National interest & $\begin{array}{l}\text { International force } \\
\text { supports one side }\end{array}$ & $\begin{array}{l}\text { Taliban should leave the } \\
\text { fight - election }\end{array}$ \\
\hline HPC4 & $\mathrm{M}$ & National interest & $\begin{array}{l}\text { International should have } \\
\text { listen to Afghan Context }\end{array}$ & $\begin{array}{l}\text { Int should support } \\
\text { election, use force }\end{array}$ \\
\hline HPC5 & $\mathrm{M}$ & Mutual respects & $\begin{array}{l}\text { International community } \\
\text { supports is highly vital }\end{array}$ & $\begin{array}{l}\text { Lack of foreign policy } \\
\text { in Afghanistan }\end{array}$ \\
\hline HPC6 & $\mathrm{F}$ & Mutual respects & $\begin{array}{l}\text { International community } \\
\text { supports is highly vital }\end{array}$ & $\begin{array}{l}\text { Int. should support } \\
\text { election \& use force }\end{array}$ \\
\hline HPC7 & $\mathrm{F}$ & Mutual respects & $\begin{array}{l}\text { International should have } \\
\text { listen to Afghan Context }\end{array}$ & $\begin{array}{l}\text { Int. community respect } \\
\text { the Int. conventions }\end{array}$ \\
\hline HPC8 & $\mathrm{F}$ & Mutual respects & $\begin{array}{l}\text { International community } \\
\text { supports is highly vital }\end{array}$ & $\begin{array}{l}\text { Int. should support } \\
\text { election \& use force }\end{array}$ \\
\hline HPC9 & $\mathrm{M}$ & National interest & $\begin{array}{l}\text { International community } \\
\text { supports is highly vital }\end{array}$ & $\begin{array}{l}\text { Lack of foreign policy } \\
\text { in Afghanistan }\end{array}$ \\
\hline HPC10 & $\mathrm{M}$ & Mutual respects & $\begin{array}{l}\text { International should have } \\
\text { listen to Afghan Context }\end{array}$ & $\begin{array}{l}\text { Int. should support } \\
\text { election, use force }\end{array}$ \\
\hline
\end{tabular}

